\title{
Industrial Wastewater Treatment Using High Rate Activated Sludge and Alum Additive
}

\author{
Mamdouh Y. Saleh, Gaber El Enany, Medhat H. Elzahar, and Mohamed Z. Elshikhipy
}

\begin{abstract}
The high rate activated sludge stage of the multiple-stage sludge treatment plant is characterized by high efficiencies of treatment, cost, and size, compared to conventional activated sludge treatment plants. A pilot plant with an industrial discharge flow of $135 \mathrm{~L} / \mathrm{h}$ was designed according to the highly loaded activated sludge stage (A-stage). The plant simulated the biological and chemical treatment of sludge by adding alum to the aeration tank in dosages of 100 , 150,200 and $250 \mathrm{mg} / \mathrm{L}$. The results clearly indicate that the highly-loaded activated sludge, the A-stage of the absorption/bio-oxidation system, has a high efficiency for the elimination of organic and inorganic matters. Without adding aluminum salt, the chemical oxygen demand, the total phosphate and the total nitrate were approximately $52.43 \%$, $47.82 \%$, and $40.09 \%$ respectively. The chemical-biological process with a dosage of $200 \mathrm{mg} / \mathrm{L}$ alum resulted in $76.07 \%$ reduced chemical oxygen demand and improved efficiency of phosphate and nitrate removal to $73.5 \%$ and $66.98 \%$ respectively compared with the biological process in the A-stage.
\end{abstract}

Index Terms-Alum, COD, industrial wastewater, nitrate, phosphate.

\section{INTRODUCTION}

Industrial activities represent an important pollutant source contributing to a significant increase in ion concentrations and contaminating bodies of water, especially considering that such ions can be disseminated through the food chain [1]. In 1910, researchers began investigations on the treatment of wastewater simply by aeration. In Manchester, similar experiments were conducted, but after a certain aeration period they stopped aeration, let the flocs settle, decanted the supernatant, and added more wastewater, repeating this cycle several times. After the buildup of a certain amount of biomass, they obtained a fully nitrified effluent at an aeration period of 6 hours. They called the settled sludge "activated sludge" [2].

Activated sludge is obtained through a biological process used to remove organics from wastewater like the trickling filter. Activated sludge processes are used to grow a biomass of aerobic organisms that will breakdown the waste and convert it into more bugs. This is accomplished in large

Manuscript received February 12, 2014; revised April 30, 2014.

Mamdouh Y. Saleh, Medhat H. Elzahar, and Mohamed Z. Elshikhipy are with the Civil Engineering Department, Faculty of Engineering, Port Said University, 42523 Port Said, Egypt (e-mail: mamsaleh29@yahoo.com, melzahar@yahoo.com, eng-moh-zak@hotmail.com).

Gaber El Enany is with the Physical Chemistry, Physical and Mathematical Engineering Department, Faculty of Engineering, Port Said University, 42523 Port Said, Egypt (e-mail: gaber71@ @otmail.com). aerated tanks, called aeration basins, instead of the trickling filter's fixed media. Activated sludge processes return settled sludge to the aeration basins in order to maintain the right amount of bugs to handle the incoming "food". Activated sludge processes have higher removal efficiencies at $95-98 \%$ than trickling filters at $80-85 \%$ [3].

The conventional process of obtaining activated sludge consists of passing wastewater through an aeration tank, a secondary clarifier and a sludge recycling line. The flow model is plug flow with cellular recycle. Both influent sewage and recycled sludge enter the tank at the head end and are aerated for a period of 6 hours. The conventional sludge load $(\mathrm{F} / \mathrm{M})$ ranges from approximately 0.2 to $0.4 \mathrm{kgBOD}_{5} /$ kgMLSS/day [4].

In Germany, researchers developed the first two-stage activated sludge plant, or $\mathrm{AB}$ system, which consists of a series of two independent activated sludge plants. The first stage is characterized by a high sludge loading rate $(\mathrm{F} / \mathrm{M})$, while the second stage has a rather low F/M. The excess sludge of the second stage is usually transferred to the first stage [2]. The absorption/bio-oxidation technique (AB-system) was invented and patented as a two-stage activated sludge plant without primary sedimentation. In this process the excess sludge of the second stage is not transferred to the first stage [2].

The sludge load (F/M) in the high-load stage (A-stage)

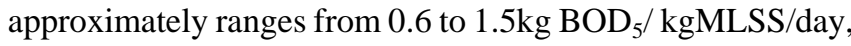
and for the low-load stage (B-stage) F/M ranges from 0.1 to $0.2 \mathrm{~kg} \mathrm{BOD} / \mathrm{kg} \mathrm{MLSS/day} \mathrm{[4].}$

The COD elimination efficiency in the A-stage is variable and easy to control. The degree of efficiency obtained can vary between $42-50 \%$ depending on the sludge load and the method of operation [4]. In the activated sludge process, a bacterial biomass suspension (the activated sludge) is responsible for the removal of pollutants. Depending on the design and the specific application, an activated sludge wastewater treatment plant (WWTP) can achieve biological nitrogen $(\mathrm{N})$ removal and biological phosphorus $(\mathrm{P})$ removal, besides removal of organic carbon substances [5].

Nitrogen is present in several forms, for example as ammonia $\left(\mathrm{NH}_{3}\right)$, ammonium $\left(\mathrm{NH}_{4}^{+}\right)$, nitrate $\left(\mathrm{NO}_{3}^{-}\right)$, nitrite $\left(\mathrm{NO}_{2}^{-}\right)$and as organic compounds. In untreated wastewater, nitrogen is mostly present in the form of $\mathrm{NH}_{4}{ }^{+}$and organic nitrogen. Nitrogen is an essential nutrient for biological growth. It is one of the main components in all living organisms. However, when nitrogen is present in influent wastewater, problems may arise [6]-[8]. Ammonia is toxic to aquatic organisms, especially for higher life forms such as fishes. When ammonium is oxidized to nitrate, a significant oxygen demand in the receiving water may give rise to a severe depletion of the dissolved oxygen concentration. 
Nitrogen is an essential plant nutrient. Overloading can stimulate undesirable growth of aquatic plants and algae. When the plants die, organisms degrading the litter consume oxygen [6]-[8].

As seen in the formulas, ammonium is first oxidized to nitrite and then to nitrate. The nitrate can be converted to nitrogen gas by de-nitrification. This process occurs in anoxic environments (oxygen only present as nitrate). The bacteria responsible for de-nitrification respire with nitrate instead of oxygen. The following sampled reaction formula shows the basic process [6]-[8].

$$
\begin{gathered}
\mathrm{NH}_{4}^{+}+1.5 \mathrm{O}_{2} \rightarrow \mathrm{NO}_{2}^{-}+\mathrm{H}_{2} \mathrm{O}+2 \mathrm{H}^{+} \\
\mathrm{NO}_{2}^{-}+0.5 \mathrm{O}_{2} \rightarrow \mathrm{NO}_{3}^{-} \\
2 \mathrm{NO}_{3}^{-}+2 \mathrm{H}^{+} \rightarrow \mathrm{N}_{2}+\mathrm{H}_{2} \mathrm{O}+2.5 \mathrm{O}_{2}
\end{gathered}
$$

Mineral additive and lime additive are the principal methods for in-plant removal of phosphorus from wastewater. The most commonly used of these metal salts is a hydrated aluminum sulfate $\left(\mathrm{Al}_{2} \mathrm{SO}_{4}\right)_{3} \cdot 18 \mathrm{H}_{2} \mathrm{O}$ [9].

\section{MODEL DESCRIPTION AND OPERATION}

\section{A. Aim of Study}

The aim of this research is to increase elimination efficiency of $\mathrm{COD}$, the total phosphate $\left(\mathrm{PO}_{4}\right)$ and Nitrate $\left(\mathrm{NO}_{3}\right)$ result as influent of industrial wastewater by adding chemical precipitants such as $\mathrm{Al}_{3}{ }^{+}$salts. The study was carried out in the first biological stage, the A-stage, which is characterized as the highly-loaded activated sludge stage of the multiple-stage plant, or AB-system.
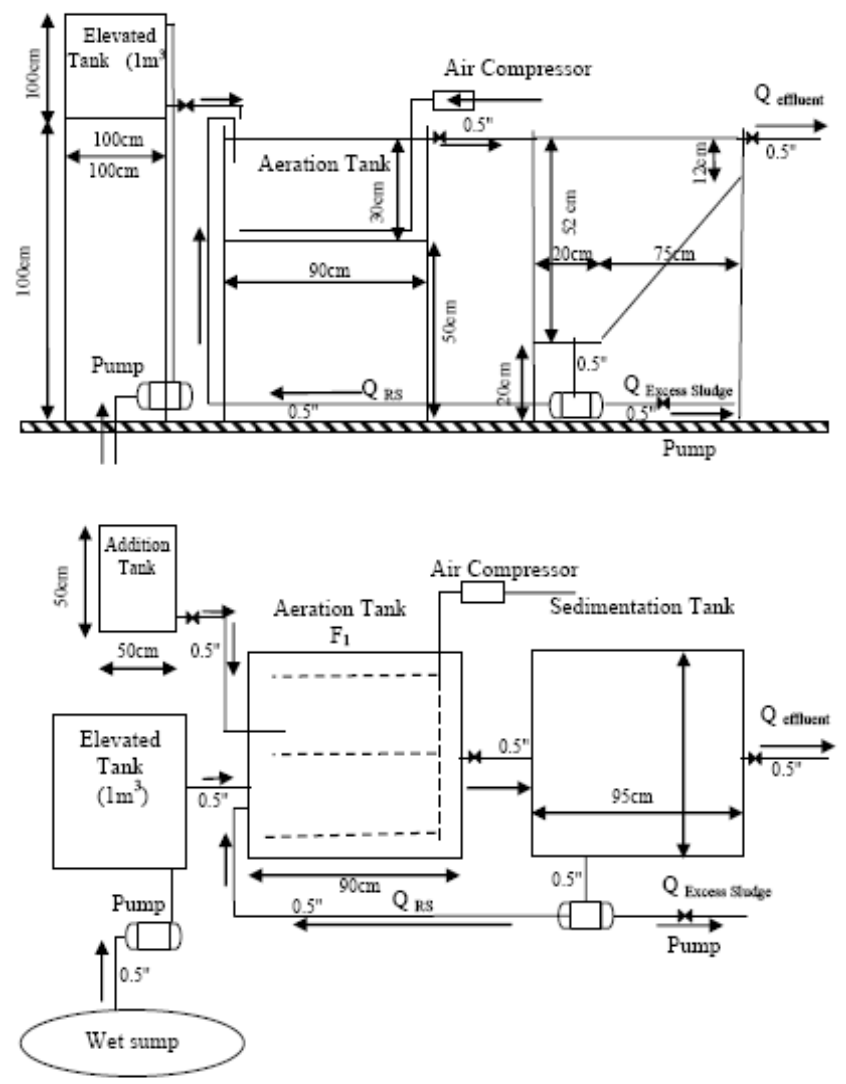

Fig. 1. Pilot plant for A-stage process.

\section{B. Model Description and Operation}

The work in this study was carried out on a scaled pilot plant. The model system used consisted of two rectangular tanks made from galvanized tin sheets. The aeration tank and the sedimentation tank, which was also the final clarifier, were modeled to act dependently as the A-System. The total volume of the aeration tank was $135 \mathrm{~L}$ with a detention time of 30 minutes. The influent flow was $135 \mathrm{~L} / \mathrm{h}$ with an average returned sludge of $135 \mathrm{~L} / \mathrm{h}$. The sedimentation tank had a total volume of $270 \mathrm{~L}$ with a detention time of one hour. The water flow was $135 \mathrm{~L} / \mathrm{h}$ with the temperature ranging from $19^{\circ} \mathrm{C}$ to $40^{\circ} \mathrm{C}$, as shown in Fig. 1.

\section{Sample Collection Points}

There were four sample collection points in the pilot plant. These points were very important in order to examine the characteristics of wastewater and sludge. The four positions were first, the influent of the pilot plant; second, the effluent of the pilot plant downstream from the settling tank; third, the influent of the recycling sludge upstream from the aeration tank; and the fourth point was at the middle of the aeration tank (i.e. the mixed liquor in the aeration tank).

\section{Chemicals Used for Precipitation (Aluminum Salts)}

Alum is acidic in nature while sodium aluminates is alkaline, which may be an important factor in choosing between them. Alum was more effective than sodium aluminates based on the molecule ratio. The commercial product for alum (aluminum sulfate), $\mathrm{Al}_{2}\left(\mathrm{SO}_{4}\right)_{3} \cdot 18 \mathrm{H}_{2} \mathrm{O}$ [9]. In this study, the alum dosages used ranged from 100 to 250mg/l.

\section{E. Analysis of Wastewater and Sludge Characteristics}

Biochemical oxygen demand $\left(\mathrm{BOD}_{5}\right)$, chemical oxygen demand $(\mathrm{COD})$, phosphate $\left(\mathrm{PO}_{4}\right)$ and nitrate $\left(\mathrm{NO}_{3}\right)$ were the parameters determined for the influent wastewater to the aeration tank and the effluent from the settling tank. The influent and effluent samples were mixed samples, which were collected during 24 hours of the day and stored in a refrigerator. The samples were taken at regular intervals 3 times a day. Samples of the returned sludge and mixed liquor were taken once a day in the morning. Ph-value, mixed liquor suspended solids (MLSS), suspended solids in the returned sludge (SSRS) and sludge load rate (F/M) were the parameters determined for the returned sludge (RS) to the aeration tank and the mixed liquor in the aeration tank (A-tank). The sludge as well as the mixed liquor samples was taken three times per day at 9.00 a.m., 11.00 a.m. and 1.00 p.m., the peak polluted times. All the parameters were determined in accordance with the American standards methods for the examination of water and wastewater [10].

\section{RESUlTS AND DISCUSSION}

This was accomplished by the addition of chemical $\left(\mathrm{Al}^{3+}\right.$ salt) to the influent to the aeration tank of the A-stage of the multiple-stage plant (AB-system). As described previously, the experimental work for this study was subdivided into two groups. The first group was carried out without salts added (zero additives). It was the starting period of the aeration tank with a mixed sludge sewage water recirculation ratio of $89 \%$. 
TABLE I: AVERAGE VALUES OF INFLUENT BOD 5 , AERATION TANK MLSS AND F/M

\begin{tabular}{llll}
\hline \hline $\begin{array}{l}\text { Alum } \\
\mathrm{mg} / \mathrm{L}\end{array}$ & $\begin{array}{l}\mathrm{BOD}_{5} \\
\mathrm{mg} / \mathrm{L}\end{array}$ & $\begin{array}{l}\text { MLSS } \\
\mathrm{mg} / \mathrm{L}\end{array}$ & $\begin{array}{l}\mathrm{F} / \mathrm{M} \\
\mathrm{mg} / \mathrm{L}\end{array}$ \\
\hline zero & 107.1 & 0.93 & 3.27 \\
100 & 135.4 & 1.48 & 2.55 \\
150 & 131.61 & 1.07 & 3.15 \\
200 & 182.8 & 1.3 & 3.65 \\
250 & 179.57 & 1.21 & 4.19 \\
\hline \hline
\end{tabular}

mg = milligram, $\mathrm{L}=$ Liter.

The second group was called out in four runs with the addition of different alum salt dosages of 100, 150, 200 and $250 \mathrm{mg} / \mathrm{L}$.

\section{A. $B O D_{5}, M L S S$ and F/M Parameters}

Table I illustrates average influent and effluent concentrations and elimination efficiencies of the $\mathrm{BOD}_{5}$, aeration tank MLSS and F/M for all of trials. The average $\mathrm{F} / \mathrm{M}$ ratios which ranged between 2.55 and $4.19 \mathrm{kgBOD}_{5} / \mathrm{kg}$ MLSS/day (F/M ratio must be equal or larger than $1.5 \mathrm{~kg}$ $\mathrm{BOD}_{5} / \mathrm{kg}$ MLSS/day [4]). This means that the pilot plant was working as highly-loaded activated sludge for all runs.

\section{B. Chemical Oxygen Demand (COD)}

Fig. 2-Fig. 4 illustrate the influent and the effluent COD average concentration values with $0,100,150,200,250 \mathrm{mg} / \mathrm{L}$ Alum. Salts additive was 9308, 7852, 8280, 3255.1, 3873.6mg/L and 4136.1, 3933.6, 1783,736, 826.71mg/L respectively. As shown in Fig. 5 and Fig. 6, The COD elimination efficiency values with $0,100,150,200,250 \mathrm{mg} / \mathrm{L}$ Alum. Salts were 52.43\%, 58.65\%, 72.67\%, 76.07 and $75.81 \%$ respectively. It means that the COD elimination efficiency increased by using higher dosages of Alum until reaching to $200 \mathrm{mg} / \mathrm{L}$, after which the efficiency rates were constant.

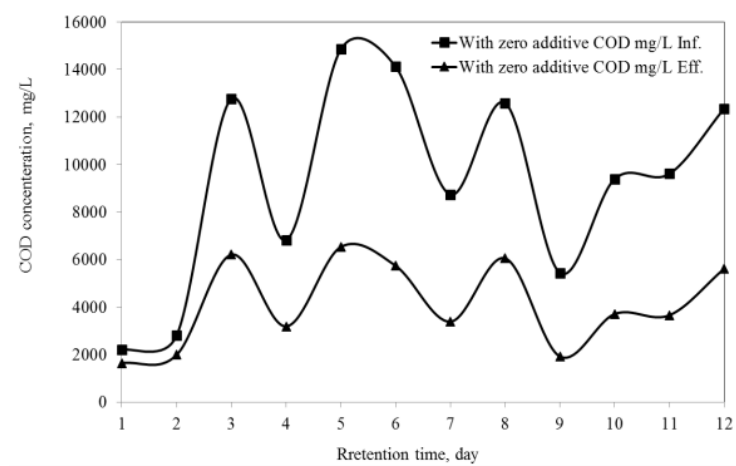

Fig. 2. Influent and effluent COD (zero additives).

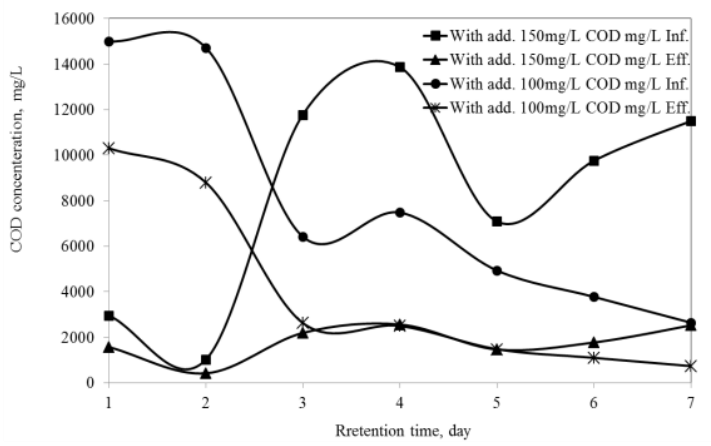

Fig. 3. Influent and effluent COD (adding 100 and 150mg/L Alum).

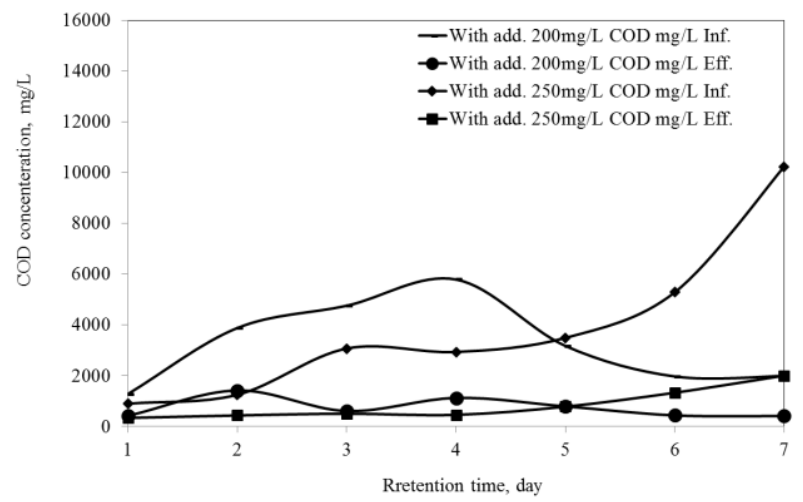

Fig. 4. Influent and effluent COD (adding 200 and 250mg/L Alum).

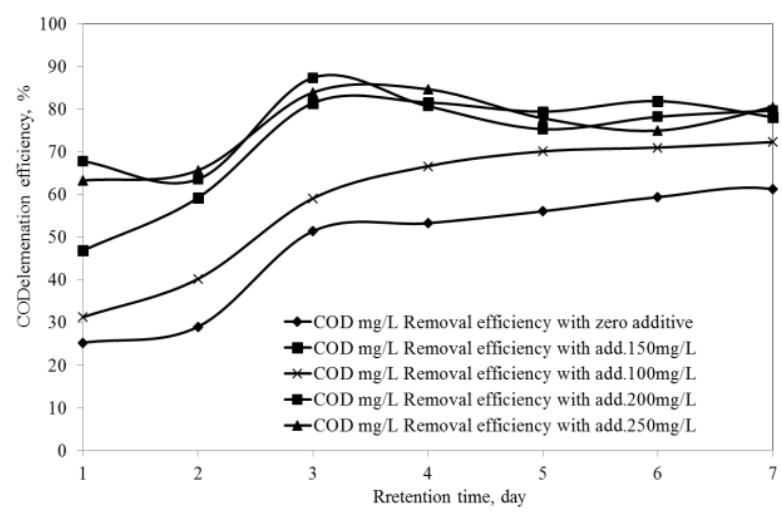

Fig. 5. COD elimination values (adding 0 to $250 \mathrm{mg} / \mathrm{L}$ Alum).

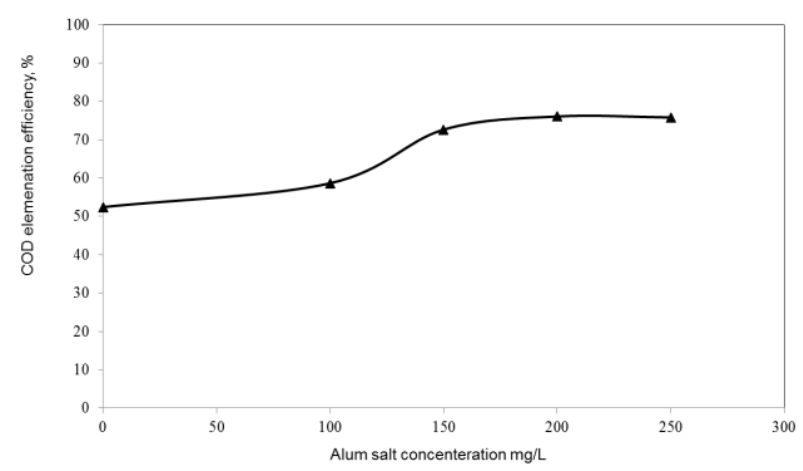

Fig. 6. Average COD elimination values (adding 0 to $250 \mathrm{mg} / \mathrm{L}$ Alum).

\section{Phosphate Removal}

Fig. 7-Fig. 9 illustrate the influent and the effluent $\mathrm{PO}_{4}$ average concentration values with $0,100,150,200,250 \mathrm{mg} / \mathrm{l}$ Alum Salts additive was 23.5, 21.59, 21.04, 6.281, 6.53mg/L and $12.5,10.8,5.807,1.664,1.39 \mathrm{mg} / \mathrm{L}$ respectively.

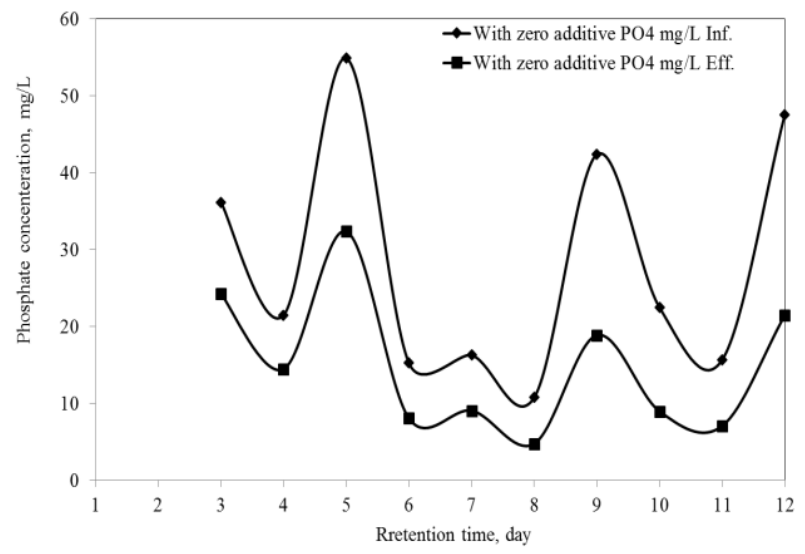

Fig. 7. Influent and Effluent $\mathrm{PO}_{4}$ (zero additives). 


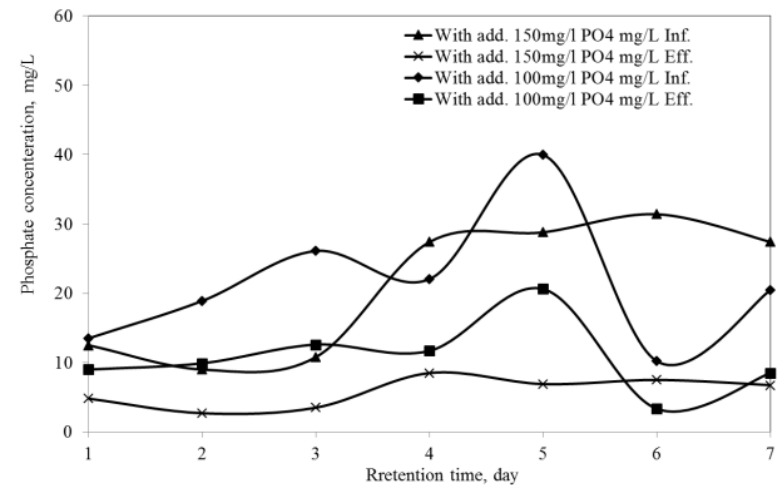

Fig. 8. Influent and effluent $\mathrm{PO}_{4}$ (adding 100 and $150 \mathrm{mg} / \mathrm{L}$ Alum).

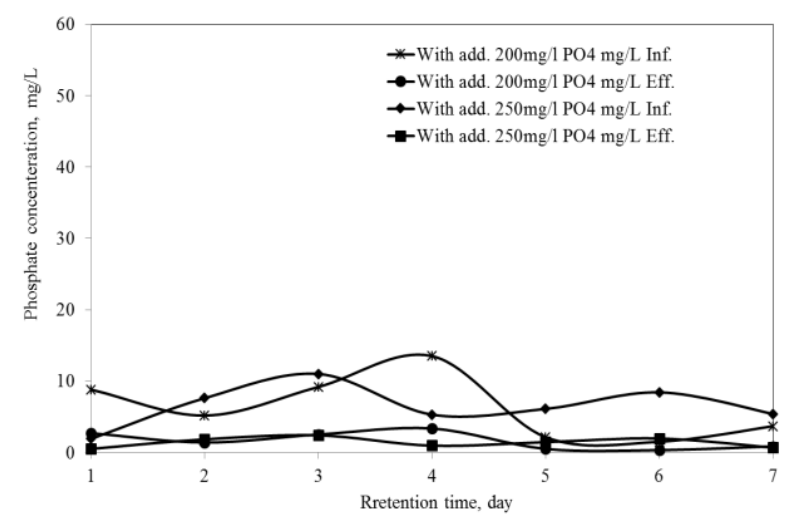

Fig. 9. Influent and effluent $\mathrm{PO}_{4}$ (adding 200 and $250 \mathrm{mg} / \mathrm{L}$ Alum).

As shown in Fig. 10, Fig. 11, the $\mathrm{PO}_{4}$ elimination efficiency values with $0,100,150,200,250 \mathrm{mg} / \mathrm{L}$ Alum. Salts were $47.82 \%, 49.96 \%, 72.41 \%, 73.5 \%$ and $78.65 \%$ respectively. This means that the efficiency of $\mathrm{PO}_{4}$ elimination increased by using higher dosages of Alum Salts until reaching to $200 \mathrm{mg} / \mathrm{L}$. After $200 \mathrm{mg} / \mathrm{L}$, the rates were almost constant.

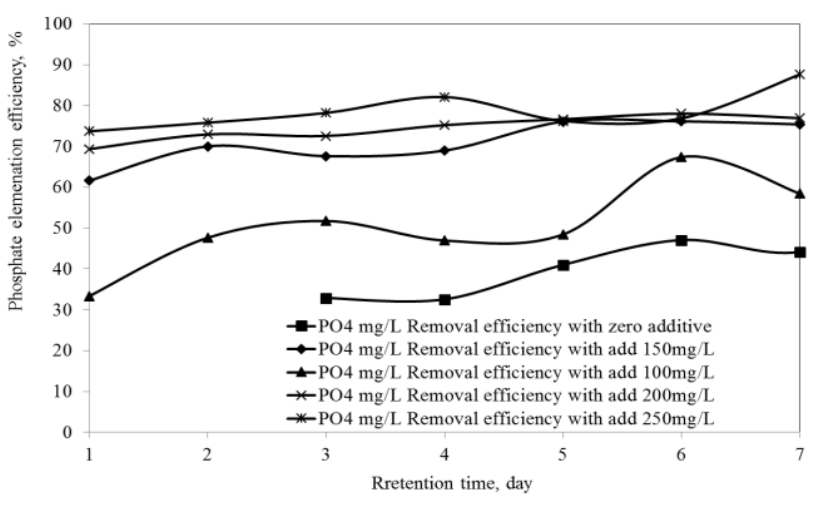

Fig. 10. $\mathrm{PO}_{4}$ Elimination values (adding 0 to $250 \mathrm{mg} / \mathrm{L}$ Alum).

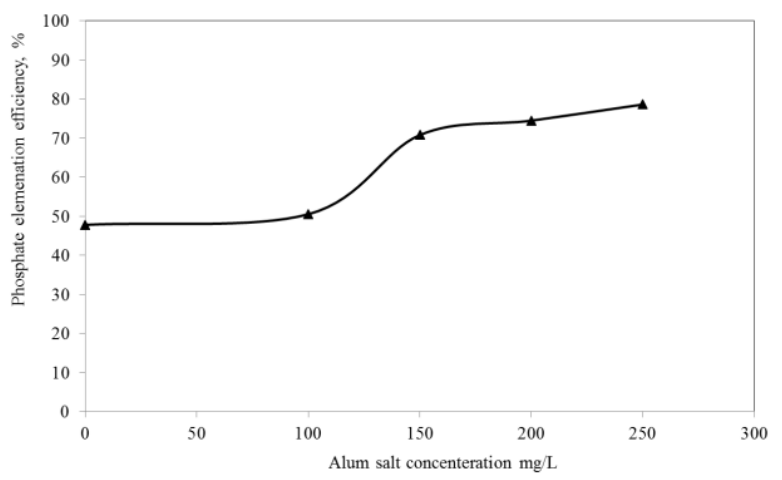

Fig. 11. Average $\mathrm{PO}_{4}$ elimination values (adding 0 to $250 \mathrm{mg} / \mathrm{L}$ Alum).

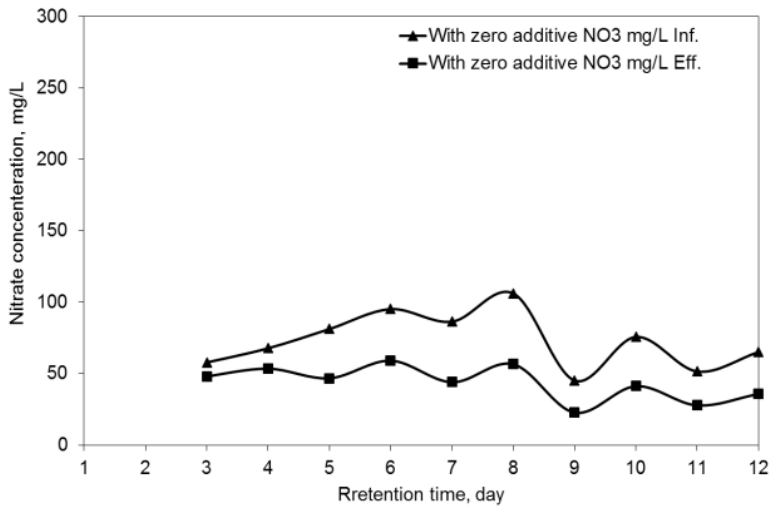

Fig. 12. Influent and effluent $\mathrm{NO}_{3}$ (zero additives).

\section{Nitrate $\left(\mathrm{NO}_{3}\right)$}

Fig. 12-Fig. 14 illustrate the influent and the effluent $\mathrm{NO}_{3}$ average concentration values with $0,100,150,200,250 \mathrm{mg} / \mathrm{L}$ Alum. Salts additive was $60.98,70.92,100.87,186.06$, $231.67 \mathrm{mg} / \mathrm{L}$ and $36.25,36.759,39.67,61.437,64.57 \mathrm{mg} / \mathrm{L}$ respectively.

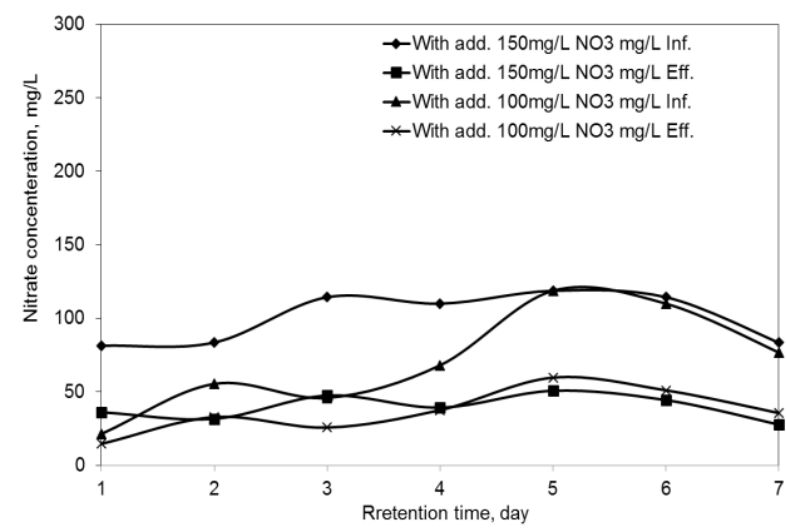

Fig. 13. Influent and effluent $\mathrm{NO}_{3}$ (adding 100 and $150 \mathrm{mg} / \mathrm{L}$ Alum)

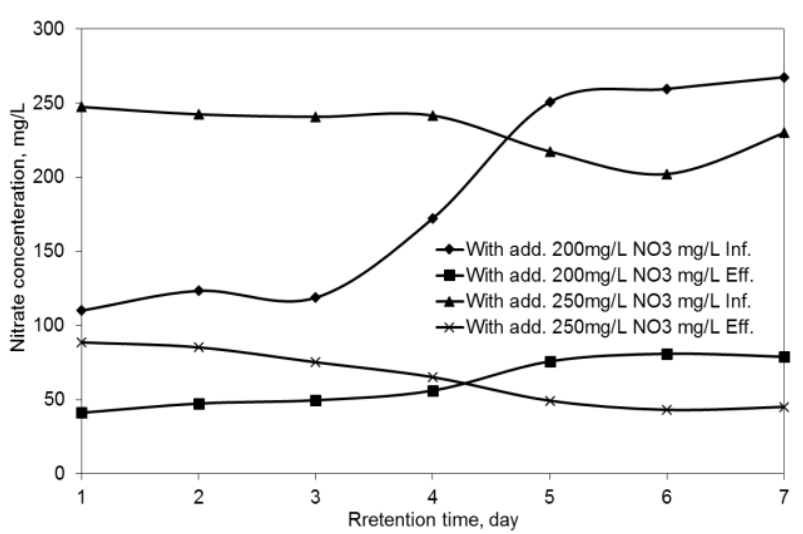

Fig. 14. Influent and effluent $\mathrm{NO}_{3}$ (adding 200 and 250mg/L Alum).

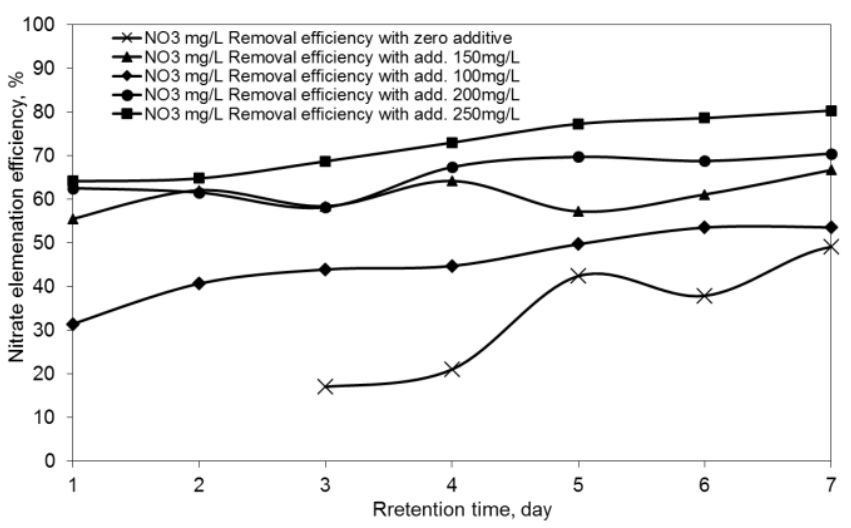

Fig. 15. $\mathrm{NO}_{3}$ Elimination values (adding 0 to $250 \mathrm{mg} / \mathrm{L}$ Alum). 


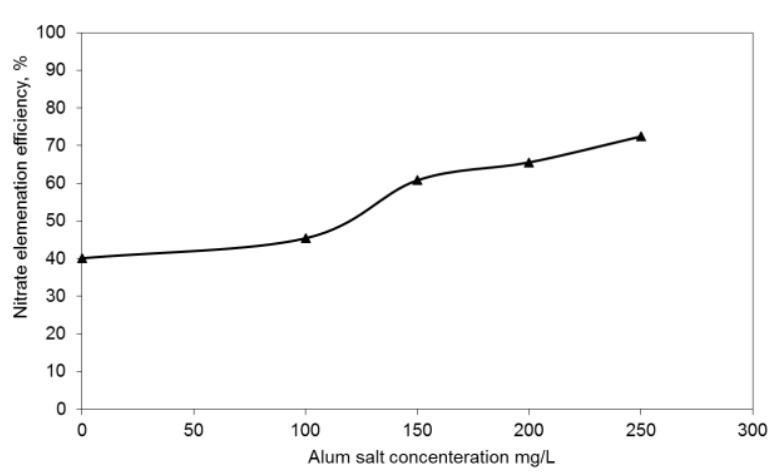

Fig. 16. Average $\mathrm{NO}_{3}$ elimination values (adding 0 to $250 \mathrm{mg} / \mathrm{L}$ Alum).

As shown in Fig. 15 and Fig. 16, the $\mathrm{NO}_{3}$ elimination efficiency values with $0,100,150,200,250 \mathrm{mg} / \mathrm{L}$ Alum. Salts were $40.09 \%, 48.17,60.67 \%, 66.98 \%$ and $72.13 \%$ respectively. This means that the $\mathrm{NO}_{3}$ elimination efficiency increased by using higher dosages of Alum Salts, until reaching to $200 \mathrm{mg} / \mathrm{L}$. After $200 \mathrm{mg} / \mathrm{L}$, the efficiency rates were constant.

\section{SUMMARY OF RESUlTS}

The results clearly indicate that the highly-loaded activated sludge (A-stage) has a high efficiency for the elimination of organic and inorganic matters compared with the mechanical stage of the conventional treatment plants. Without adding aluminum salt (zero additives), the removal efficiency of the chemical oxygen demand (COD), the total phosphate $\left(\mathrm{PO}_{4}\right)$ and nitrate $\left(\mathrm{NO}_{3}\right)$ were approximately $52.43 \%, 47.82 \%$, and $40.09 \%$ respectively. Adding aluminum salt improved the elimination efficiency of COD, the total phosphate $\left(\mathrm{PO}_{4}\right)$ and nitrate $\left(\mathrm{NO}_{3}\right)$ in the first treatment stage.

A pilot plant with an influent discharge flow of $135 \mathrm{~L} / \mathrm{h}$ was designed according to the highly loaded activated sludge stage (A-stage) of the multiple-stage plant (AB-system) to simulate between the biological and chemical treatment with the addition of alum sulfate to the aeration tank with dosages of $100,150,200$ and $250 \mathrm{mg} / \mathrm{L}$. The average $\mathrm{F} / \mathrm{M}$ ratios increased incrementally as the dosage of the aluminum salt increased. In addition, the ratios were higher than the values of the conventional activated sludge unit. The average F/M ratio with $100,150,200$ and $250 \mathrm{mg} / \mathrm{L}$ aluminum salt added were found to be $2.553,3.516,3.645$ and $4.158 \mathrm{KgBOD}_{5} /$ $\mathrm{KgMLSS} /$ day, respectively. Aerated mixed liquor can be classified as highly-loaded activated sludge because all over

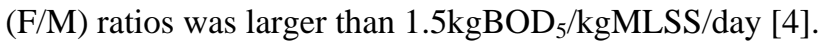

The COD elimination efficiency values with dosages of 0 , $100,150,200,250 \mathrm{mg} / \mathrm{L}$ aluminum salts were $52.43 \%$, $58.65 \%, 72.67 \%, 76.07$ and $75.81 \%$ respectively. This means that the COD elimination efficiency increased by increasing the dosage of aluminum salts until reaching to $200 \mathrm{mg} / \mathrm{L}$, as with the higher dosage the efficiency remained constant. The degree of efficiency was attained to be more than $42-50 \%$ achieved without adding alum (the COD depending on the sludge load (F/M) and the method of operation) [4]. However, in our case, all effluent COD values were more than the allowable range $100 \mathrm{mg} / \mathrm{L}$ [11] .

The influent and effluent phosphate $\left(\mathrm{PO}_{4}\right)$ elimination efficiencies increased with time. The $\mathrm{PO}_{4}$ elimination efficiency values with dosages of $0,100,150,200,250 \mathrm{mg} / \mathrm{L}$ aluminum salts added were $47.82 \%, 49.96 \%, 72.41 \%, 73.5 \%$ and $78.65 \%$ respectively. The $\mathrm{PO}_{4}$ elimination efficiency in the A-stage met and exceeded the phosphate elimination range of 47-63\% achieved without adding alum. All effluent values of $\mathrm{PO}_{4}$ were less than the allowable value of $10 \mathrm{mg} / \mathrm{L}$ [11].

The influent and effluent nitrate $\left(\mathrm{NO}_{3}\right)$ elimination efficiencies increased with time. The $\mathrm{NO}_{3}$ elimination efficiency values with dosages of $0,100,150,200$, and $250 \mathrm{mg} / \mathrm{L}$ aluminum salts added were $40.09 \%$, 48.17, $60.67 \%$, $66.98 \%$ and $72.13 \%$ respectively. The $\mathrm{NO}_{3}$ elimination efficiencies met and exceeded the nitrate elimination range of 50-60\% achieved without adding alum [4].

\section{CONCLUSION}

Based on the observations and the results obtained, the following points can be concluded:

1) The detention time of 30 minutes in the A-tank is sufficient for mixing and flocculation of the mineral salt.

2) Adding aluminum salt in the influent of the highly-loaded activated sludge stage (A-stage) of the multiple-stage plant (AB-system) improved the elimination efficiency of COD, as well as the removal of phosphate and nitrate.

3) The optimization of the chemical-biological process using $200 \mathrm{mg} / \mathrm{L}$ alum dosage compared with the biological process in the A-stage resulted in the following advantages:

- Improved COD removal efficiency from $52.43 \%$ without additive to $76.07 \%$.

- Improved phosphate removal efficiency from $47.82 \%$ without additive to $73.5 \%$.

- Improved nitrate removal efficiency from $40.09 \%$ without additive to $66.98 \%$.

\section{REFERENCES}

[1] C. G. Rocha, D. A. Zaia, R. V. Alfaya, and A. A. Alfaya, "Use of rice straw as biosorbent for removal of $\mathrm{Cu}(\mathrm{II}), \mathrm{Zn}$ (II), $\mathrm{Cd}(\mathrm{II})$ and $\mathrm{Hg}(\mathrm{II})$ ions in industrial effluents," Journal of Hazardous Materials, vol. 166 , no. 1 , pp. 383-388, 2009

[2] R. Kayser, "Activated sludge process," in Environmental Biotechnology Concepts and Applications, H. J. Jördening and J. Winter, Eds. Weinheim, FRG: Wiley-VCH Verlag GmbH \& Co. $\mathrm{KGaA}, 2005$, ch. 3.

[3] F. Ragsdale. (July 2013). Wastewater system operator's manual. Ragsdale and Associates Training Specialists. [Online]. Available: http://ragsdaleassociates.com/WastewaterStudy.htm

[4] M. Y. Saleh, "Optimization of highly loaded biological stage treatment of wastewater by adding flocculants," Ph.D. dissertation, Dept. Civ. Eng., Suez Canal Univ., Port Said, Egypt, 1994.

[5] K. V. Gernaey, M. van Loosdrecht, M. Henze, M. Lind, and S. B. Jørgensen, "Activated sludge wastewater treatment plant modelling and simulation: state of the art," Environmental Modelling \& Software, vol. 19 , no. 9, pp. 763-783, January 2004

[6] B. Carlsson and C. F. Lindberg. (August 2004). Some control strategies for the activated sludge process. Dept. of Systems and Control course notes, Uppsala University, Sweden. [Online] Available: http://www.it.uu.se/edu/course/homepage/h2orentek/WWT98/Control WWTP2004.pdf

[7] C. P. Wu, "Ammonia wastewater treatment by immobilized activated sludge," Bach. of Sci. dissertation, Fac. of Worcester Polytechnic Institute, Shanghai Jiao Tong University, Shanghai, China, 2010.

[8] C. F. Lindberg, "Control and estimation strategies applied to the activated sludge process," Ph.D. dissertation, Dept. of Materials Science, Uppsala Univ., Uppsala, Sweden, 1997. 
[9] J. P. Guyer, An Introduction to Advanced Wastewater Treatment, Stony Point, New York, NY: Continuing Education and Development, 2011.

[10] Standard Methods for the Examination of Water and Wastewater, American Public Health Association, Water Environment Federation, 1999.

[11] Controls, Standards and Specifications, Regardless of Liquid Wastes into Waterways, Egyptian Ministry of Health, Law No.48, Cairo, Egypt, 1982.

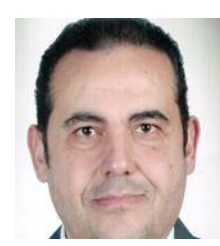

Mamdouh Youssif Saleh is a professor in the Civil Engineering Department, specializing in sanitary and environmental engineering with an emphasis on wastewater treatment since 2009. His research focuses on using A-B waste activated sludge system for wastewater treatment. He was born in Port Said, Egypt in 1961. He was graduated from Faculty of Engineering, Suez Canal University in 1985. He received his M.Sc. degree in civil engineering from Suez Canal University, 1990. His got his Ph.D. degree in sanitary and environmental engineering in 1994, and completed via a cooperative research program between Suez Canal University, Port Said, Egypt and Aachen University, Aachen, Germany. He has more than 22 international journal/conference papers published.

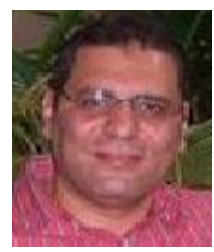

Gaber Mohamed Elenany is an associate professor in the Physical and Mathematical Engineering Department since 2012 in Faculty of Engineering, Port Said University, Port Said, Egypt. He was born in Ismailia, Egypt in 1969. He was graduated in 1993 from the Chemistry Department, Faculty of Science, Ain Shams University, Egypt. He received his M.Sc. degree in 1998 from the same Department, Suez Canal University. He received his Ph.D. degree in Suez Canal University on applied physical chemistry in 2004. His research interests are focusing on conductivity polymers applications, energy storage applications and sensors. He was a visiting professor to South Hampeton University, England in 2012.

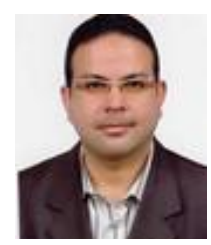

Medhat Hosny Elzahar is an assistant professor specializing in environmental engineering with an emphasis on sanitary and environmental hydraulics. His research focuses on developing new techniques for the treatment and re-use of sludge, a by-product of water treatment facilities, developing innovative techniques to treat domestic and industrial wastewater using greenhouse-gas emissions, and improving and utilizing optimal designs for sedimentation and filtration units. He was born in Port Said, Egypt in 1969. He got the Ph.D. in sanitary and environmental hydraulics in 2003, and completed via a cooperative research program between Suez Canal University, Egypt, and the Kyushu Institute of Technology, Kitakyushu, Japan. He got the M.Sc. degree in environmental hydraulics in 1997 from Suez Canal University, Port Said, Egypt. He got the B. Sc. in civil engineering in 1992 from Suez Canal University, Port Said, Egypt. He works as an assistant professor in Port Said University, Egypt from 2003 to present. He has over 20 international journal/conference publications. He introduced a new technique by using green house gas for flotation of waste activated sludge.

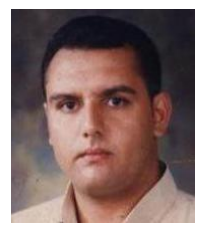

Mohamed Zakarya Elshikhipy is a lecturer and Ph.D. candidate in the Civil Engineering Department, Faculty of Engineering, Port Said University, Port Said, Egypt. He was born in Port Said, Egypt in 1977. He was graduated from the same Department in 1999. He received his M.Sc. degree from the same Department in 2007. His Ph.D. dissertation is focusing on industrial wastewater treatment using chemical additives and high rate activated sludge system. He is following the procedure and waiting the approval of his thesis to receive his Ph.D. degree within this year. 